\title{
Studies on Isolation of Yeast and Its Comparative Performance for Quality Wine Production from Pineapple and Sapota
}

\author{
Anjali Gaharwar, R. M. Shinde*, D. L. Wasule, R. D. Bharsakhale, \\ M. P. Yelme, Khode Vaibhavi and Manisha Sonule \\ Vasantrao Naik College of Agricultural Biotechnology, Yavatmal, India \\ *Corresponding author
}

\section{A B S T R A C T}

Keywords

Yeast,

Saccharomyces

cerevisiae,

Pineapple, PI-1,

MY-1, sapota,

fermentation,

organoleptic

analysis, wine

Article Info

Accepted:

15 December 2019

Available Online:

20 January 2020
A study on 'Comparative Performance of yeasts for Quality Wine Production' was carried out at Vasantrao Naik College of Agricultural Biotechnology, Yavatmal during the year 2019-20. Two different yeast strains PI-1 and PI-2 were isolated from rotten pineapple (Ananus comosus ) juice using YEPD medium. The isolated strains tested and confirmed to yeast Saccharomyces cerevisiae. These two identified strains PI-1 and PI-2 were studied for capability of fermentation activity for quality wine production and found PI-1 found to be of good capability for wine production. The experiment was conducted with an objectives to study the comparative performance of isolated PI-1 yeast with Market yeast Saccharomyces cerevisiae for quality wine preparation from pineapple and sapota. In the said experiment extracted pineapple and sapota juice each were inoculated with $5 \%$ yeast PI-1 and 5\% MY-I i.e. of Saccharomyces cerevisiae respectively to form four treatments conducted in five sets of replications and allowed for primary fermentation for 6-10 days. The juice sugar was maintained to $20{ }^{\circ} \mathrm{B}$. After 30 days of secondary fermentation, clarified the wine with bentonite clay $0.1 \%$. The pineapple and sapota wines from four treatments were analyzed for physiochemical properties and organoleptic evaluation after 30 days of fermentation. From the observations recorded, it was found that, the yeast isolate PI-1 of Saccharomyces cerevisiae recorded maximum fermentation in wine as reported minimum TSS, total sugar, higher percentage of titrable acidity, ascorbic acid and alcohol.

\section{Introduction}

Pineapple (Ananas comosus) is a tropical and subtropical fruit and the most economically significant plant in the family Bromeliaceae. Pineapples are having fascinating nutritional benefits, contain good sugar proportion which makes it suitable for wine making (Adaikan and Ganesan,2004).Fruit contain high amount of vitamin $\mathrm{C}(58 \%)$ and manganese, which is important for antioxidant defenses and essential in developing strong bones and connective tissue.

Unlike other fruits, it contains "Bromelain" - a proteolytic enzyme that break down protein and helps in drug digestion (Tochi et al., 2008). Sapota (Manilkara zapota L.) is a 
perennial fruit crop belongs to family Sapotaceae. Matured sapota pulp is a good source of carbohydrates $(21.4 \mathrm{~g} / 100 \mathrm{~g})$, dietary fiber $(10.9 \mathrm{~g} / 100 \mathrm{~g})$, tannin $(3.16-3.45 \%)$, ascorbic acid and minerals like calcium (28 $\mathrm{mg} / 100 \mathrm{~g}$ ) and phosphorus (27 $\mathrm{mg} / 100 \mathrm{~g})$. Sapota fruits also a good source of sugar, antioxidant, minerals, ascorbic acid and vitamins, may have good scope for industrial and medicinal application. The sapota fruits are good source of sugar which ranges from 12 to $18 \%$ have a great potential to convert it into alcohol and thereby to flourish post harvest industry for preparation of fermented products like wine.

Wine is an alcoholic beverage typically made of fermented fruit juice. Wine fermentation has two distinct stages: Primary and Secondary (also described as aerobic and anaerobic) fermentations (Berry,1996; Jacobs,2001).Application of yeast for fermentation in food products is the oldest and largest biotechnology application. Intensive researches has been carried out for obtaining efficient and low cost fermentative organisms that determines the product quality.

The yeast Saccharomyces cerevisiae being marketed as brewer's yeast is well known for its fermentation activity. But the different strains of the yeast meant to produce a quality difference in product. Market yeast is the common name for the strains of yeast commonly used in bakery industry. The Market yeast is the species Saccharomyces cerevisiae, and is the same species (but a different strain) as the kind commonly used in alcoholic fermentation, which is called brewer's yeast that is used to compare the performance with Isolated yeast for quality wine production. The attempt has been made to obtained the yeast strain and study the proximate composition and sensory attributes of both the pineapple and sapota wines with different yeasts for quality preparation.

\section{Materials and Methods}

The laboratory experiment was carried out in two phases.

Isolation of yeast from rotten pineapple juice

The yeast spp. were isolated from rotten pineapple juice using $1 \mathrm{ml}$ of extracted juice sample inoculated on the YEPD media plates and kept at $37^{\circ} \mathrm{C}$ for 72 hours for incubation. The colonies grown on the media plate were observed to be of two different yeast colonies. These two isolated colonies were further inoculated onto two different YEPD media plates for preparation of pure culture of both the colonies. The obtained pure cultures were denoted as PI-1 and PI-2. These isolates PI-1 and PI-2 were characterized for confirmation of yeast Saccharomyces cerevisiae through morphological, biochemical and physiological tests. tested for various physiochemical, biochemical, morphological, and strain quality characterization test as suggested by Nasir Armanual et al. 2017 and Saha Jayata et al. 2016, and Hi Media Kit to confirm the yeast type.

Comparative study of yeast for wine preparation

The comparative performance study of yeasts for wine preparation was carried out with four treatments viz., Pineapple wine with PI-1 isolate, Pineapple wine with Brewer's yeast Saccharomyces cerevisiae. Sapota wine with PI-1 isolate and Sapota wine with Market Yeast. For carrying out the experiment, the mature, fresh fully ripened fruits of pineapple (Giant queen) and sapota (Cricket ball) were taken washed, peeled, extracted the fruits pulp and crushed in the mixer to obtain juice.

Pineapple juice and sapota juice obtained were filtered through muslin cloth and allowed for the precipitation of mucilage for a day. The 
filtered juice were pasteurized to avoid other bacterial contamination at $64{ }^{\circ} \mathrm{C}$. The juice samples of pineapple and sapota were analyzed for physiochemical properties and then maintained TSS to $20^{\circ} \mathrm{B}$ and kept for the primary fermentation. The juice samples were collected in sterile containers for secondary fermentation.

\section{Inoculation of yeast}

The isolated yeast strain of Saccharomyces cerevisiaePI-1 was inoculated by adding the $5 \%(250 \mathrm{ml})$ of broth in containers of pineapple and sapota juice in five sets of replications. However, for Market yeast the yeast was first dissolved in lukewarm water, stirred until it completely dissolved into it, retained it for 10$15 \mathrm{~min}$ and then added $0.5 \%$ of yeast into the containers of pineapple and sapota juice for fermentation as per PI-1.

\section{Fermentation process}

The containers inoculated with isolated yeast and market yeast kept closed. Then the mixture was incubated at $20^{\circ} \mathrm{C}$ for 7 days. The total sugar, total acid and alcohol content were monitored periodically during the fermentation. When the main fermentation finished, the supernatant liquid was transferred to other clean containers in order to remove impurities. Then the mixture continued to ferment at $20^{\circ} \mathrm{C}$ for a period of 30 days. During maturation, the wines were racked regularly.

\section{Physicochemical analysis of wine}

The wine samples of four types were clarified by adding Bentonite clay @ 0.01\% after 30 days of fermentation. The wines prepared were further analyzed for physiochemical parameters like $\mathrm{pH}$, TSS, titrable acidity, ascorbic acid, reducing sugar, non reducing sugar, total sugar and alcohol percentage by Ranganna method (1977).The wine samples were evaluated for the overall acceptability score using 20 points Hedonic scale as suggested by Amerine et al. 1972 .

\section{Sensory evaluation}

A bottle of Pineapple Wine "Pineapple Blanc" was utilized as reference standard sample for the preference test between commercial wine and the fruit wines prepared from pineapple and sapota. The panelists were made familiar for all the quality attributes of a good wine. The reference sample of market wine and the pineapple and sapota wine produced were refrigerated at $11^{\circ} \mathrm{C}$ for $24 \mathrm{hrs}$. prior to evaluation.

Each panelist from a panel of 10 judges was served the wine sample coded as unknown sample 1 to 4 in a random presentation order for the Organoleptic sensory evaluation with standard market wine, Jackson et al., 2003. Coded samples were assessed organoleptically using a 20-point hedonic scale as suggested by Amerine et al. 1972, where 15-20 correspond to "Good quality", 11-14.99 corresponds to "Medium quality" and 1-10 corresponds to "Poor quality".

\section{Results and Discussion}

Selection of suitable pineapple isolate for wine making

The isolated yeast strains were characterized through various morphological, biochemical parameters (Citrate test, Urease test, Fermentation of carbohydrates test, Hydrogen sulphide test, Killer toxic test, Antibiotic resistance test, Ethanol tolerance test and Flocculation test), physiochemical ( $\mathrm{pH}$, temperature and salt concentration) for confirmation of isolated yeast strain for Saccharomyces cerevisiae and confirmed both the isolates belong to yeast $S$. cerevisiae. These two different isolated strains PI-1 and PI-2 were also studied for fermentation 
quality, volatile acid and alcohol production. Physiological tests regarding effect of $\mathrm{pH}$ supported by Narendranath and Power, 1984, temperature, salt concentration supported by Ortiz-Zamora et al., 2009, the PI-1 isolate was found best suited for wine production as compared to PI-2 yeast.

The tests regarding characterization of yeast based on for fermentation power, foam production volatile acid production and alcohol production again the isolate pineapple strain PI-1 of Saccharomyces cerevisiae was found suitable for fermentation activities, the results are supported with the findings of Vaugham Martini et al., 1998; Palmieri et al., 1996; and Nasir Armanul et al., 2017.

Thus from all the test conducted morphological, biochemical, physiochemical tests, edible source and quality characterization, pineapple isolate -1 of Saccharomyces cerevisiae was found of good quality. The results are in confirmation with the work carried out by Saha Jayata et al. 2016, Nasir Armanual et al. 2017.

Physiochemical properties of pineapple and sapota fruit juice

The fresh ripened fruits of pineapple and sapota were processed for extraction of fruit juices and thereafter the extracted juice samples were analysed for different physiochemical parameters.

\section{Physiochemical parameters wine pH}

From the data presented in table 2, all the wines showed $\mathrm{pH}$ ranged from 3.05 to 3.35 reported the increasing trend of $\mathrm{pH}$ with days of fermentation. It was due to utilization of sugar and decreased in TSS with fermentation activity. The isolate PI-1 gave good response to fermentation than the Brewers yeast in both the fruit wines. Nasir et al., 2017 and Aakriti
Guleria et al., 2014.

\section{Total soluble solids}

Data from table 2, reported that, Sapota wine recorded minimum TSS $\left(7.34^{\circ} \mathrm{B}\right)$ with PI-1 followed by $8.21^{\circ} \mathrm{B}$ with MY-1 as compared to pineapple wine that recorded minimum TSS 9.0 $0^{\circ} \mathrm{B}$ with PI-1 followed by MY-1. Decreased in TSS from $20^{\circ} \mathrm{B}$ in all the wines with increased in days of fermentation justified the utilization of wine sugar for fermentation activities by yeast. The results are confirmed by Gautam and Chundawat, 1998, Gaharwar, 2017 and Saha Jayata et al., 2016.

\section{Sugar contents in wine}

The reducing, non reducing and total sugar contents in wine were found influenced by the yeasts used for fermentation of wines. The PI1 isolated yeast was found to be superior than MY-1 for reducing the sugar in both the fruit wines.Idolo Ifie, et al. 2012, Gaharwar et al., 2018 and Panda et al., 2014.

\section{Titrable acidity}

Maximum titrable acidity was found in pineapple wine $1.35 \%$ followed by sapota wine $1.21 \%$ both prepared from PI-1 isolated yeast strain. Market yeast recorded to produce minimum titrable acidity in fruit wines as compared to isolated yeast strain (table 3 ). The increase in titrable acidity in wine may possibly due to the production of certain salts derived from mineral acids or organic acids.

The results are supported by the work of Akriti Guleria, 2014, Thoukis et al., 1965 who confirmed that, total acid levels increased in fermented medium during alcoholic fermentation by yeast. Idise and Emmanuel, 2012 supported the increased titrable acidity due to the occurrence of microbial succession with varying tolerance for the metabolic end products. 
(I) Table Physiochemical tests results for PI-1 isolated yeast for $\mathrm{pH}$, temperature and salt concentration

\begin{tabular}{|c|c|c|c|c|c|c|c|c|}
\hline \multirow[t]{2}{*}{$\begin{array}{l}\text { pH } \\
\text { level }\end{array}$} & \multicolumn{2}{|c|}{$\begin{array}{l}\text { PINEAPPLE } \\
\text { ISOLATE PI-1 }\end{array}$} & \multirow{2}{*}{$\begin{array}{l}\text { Temp. } \\
\left({ }^{0} \mathrm{C}\right)\end{array}$} & \multicolumn{2}{|c|}{$\begin{array}{l}\text { PINEAPPLE } \\
\text { ISOLATE PI-1 }\end{array}$} & \multirow[t]{2}{*}{$\begin{array}{c}\mathrm{NaCl} \\
\text { percentage }\end{array}$} & \multicolumn{2}{|c|}{$\begin{array}{c}\text { PINEAPPLE } \\
\text { ISOLATE PI-1 }\end{array}$} \\
\hline & $\begin{array}{l}\text { Initial } \\
\text { (OD) }\end{array}$ & $\begin{array}{l}\text { After } 48 \\
\text { hrs of } \\
\text { growth } \\
\text { (OD) }\end{array}$ & & $\begin{array}{l}\text { Initial } \\
(\mathrm{OD})\end{array}$ & $\begin{array}{l}\text { After } 48 \text { hrs } \\
\text { of growth } \\
\text { (OD) }\end{array}$ & & $\begin{array}{l}\text { Initial } \\
(\mathrm{OD})\end{array}$ & $\begin{array}{l}\text { After } 48 \\
\text { hrs of } \\
\text { growth } \\
\text { (OD) }\end{array}$ \\
\hline 1 & 0.356 & 1.112 & 25 & 0.269 & 1.435 & 6 & 0.204 & 0.877 \\
\hline 2 & 0.211 & 0.717 & 30 & 0.346 & 1.537 & 9 & 0.237 & 0.246 \\
\hline 3 & 0.255 & 1.488 & 32 & 0.322 & 1.730 & 12 & 0.242 & 0.248 \\
\hline 4 & 0.559 & 2.420 & 37 & 0.441 & 2.236 & 15 & 0.197 & 0.154 \\
\hline 5 & 0.519 & 2.171 & 40 & 0.461 & 2.079 & 18 & 0.290 & 0.184 \\
\hline 6 & 0.515 & 0.501 & 44 & 0.482 & 0.848 & 20 & 0.257 & 0.197 \\
\hline
\end{tabular}

(II) Table Test by Saha Jayata et al. 2016, Nasir Armanual et al. 2017

\begin{tabular}{|l|c|c|c|c|c|}
\hline $\begin{array}{c}\text { Pineapple } \\
\text { isolates [PI] }\end{array}$ & $\begin{array}{c}\text { Morphological } \\
\text { tests }\end{array}$ & $\begin{array}{c}\text { Biochemical } \\
\text { tests }\end{array}$ & $\begin{array}{c}\text { Physiochemical } \\
\text { tests }\end{array}$ & $\begin{array}{c}\text { Edible } \\
\text { source }\end{array}$ & $\begin{array}{c}\text { Quality } \\
\text { characteriz } \\
\text { ation }\end{array}$ \\
\hline $\begin{array}{l}\text { Pineapple } \\
\text { isolate-1 } \\
\text { [PI-1] }\end{array}$ & $\begin{array}{c}\text { Round circular } \\
\text { milky white } \\
\text { opaque }\end{array}$ & $\begin{array}{c}\text { Accurate } \\
\text { results }\end{array}$ & Accurate results & Yes & $\begin{array}{c}\text { Good } \\
\text { quality }\end{array}$ \\
\hline $\begin{array}{l}\text { Pineapple } \\
\text { isolate -2 } \\
\text { [PI-2] }\end{array}$ & $\begin{array}{l}\text { Round circular } \\
\text { red rust opaque }\end{array}$ & $\begin{array}{c}\text { Near to } \\
\text { accurate } \\
\text { results }\end{array}$ & $\begin{array}{c}\text { Near to accurate } \\
\text { results }\end{array}$ & Yes & Average \\
quality
\end{tabular}

Table.1 Physicochemical properties of pineapple and Sapota fruit juice

\begin{tabular}{|l|c|c|}
\hline Parameters & Pineapple & Sapota \\
\hline Average fruit weight $\mathbf{( k g )}$ & $1 \mathrm{~kg}$ & $1 \mathrm{~kg}$ \\
\hline Weight of pulp $\mathbf{( k g )}$ & $750 \mathrm{~g}$ & $110 \mathrm{~g}$ \\
\hline Color & Pale yellow & brownish \\
\hline pH recovery & 3.74 & 4.62 \\
\hline $\begin{array}{l}\text { Juice } \\
\text { percentage } \\
\text { (Diluted with water) }\end{array}$ & $65 \%$ & $30 \%$ \\
\hline \begin{tabular}{l} 
TSS( $\circ$ B) \\
\hline
\end{tabular} & & \\
\hline
\end{tabular}


Table.2 TSS and sugar content of Pineapple and Sapota wine as influenced by Isolated and Market yeast strains

\begin{tabular}{|l|c|c|c|c|c|}
\hline Treatment for White & $\mathbf{p H}$ & $\begin{array}{c}\text { Total } \\
\text { wine }\end{array}$ & & \multicolumn{2}{|c|}{ Sugar content in wine (\%) } \\
& & $\begin{array}{c}\text { Soluble } \\
\text { Solid } \\
\left.\mathbf{(}^{\mathbf{0}} \mathbf{B}\right)\end{array}$ & $\begin{array}{c}\text { Reducing } \\
\text { sugar }\end{array}$ & $\begin{array}{c}\text { Non } \\
\text { reducing } \\
\text { sugar }\end{array}$ & $\begin{array}{c}\text { Total } \\
\text { sugar }\end{array}$ \\
\hline Pineapple wine with PI-1 & 3.05 & $9.0^{\circ} \mathrm{B}$ & 7.85 & 1.05 & 8.9 \\
\hline Pineapple MY-1 wine & 3.24 & $13.0^{\circ} \mathrm{B}$ & 8.37 & 4.59 & 12.96 \\
\hline Sapota PI-1 wine & 3.16 & $7.34^{\circ} \mathrm{B}$ & 6.41 & 0.89 & 7.3 \\
\hline Sapota MY-1wine & 3.35 & $8.21^{\circ} \mathrm{B}$ & 6.6 & 1.68 & 8.28 \\
\hline
\end{tabular}

Table.3 Titrable acidity, ascorbic acid and alcohol content of Pineapple and Sapota wine as influenced by Isolated and Market yeast strains

\begin{tabular}{|l|c|c|c|}
\hline $\begin{array}{l}\text { Treatment for White } \\
\text { wine }\end{array}$ & $\begin{array}{c}\text { Titrable acidity } \\
\mathbf{( \% )}\end{array}$ & $\begin{array}{c}\text { Ascorbic } \\
\text { acid } \\
(\mathbf{1 0 0 m g / m l )}\end{array}$ & $\begin{array}{c}\text { Alcohol } \\
\text { content } \\
(\mathbf{\%})\end{array}$ \\
\hline Pineapple wine with PI-1 & 1.35 & 4.72 & 12.12 \\
\hline Pineapple MY-1 wine & 1.0 & 3.97 & 10.21 \\
\hline Sapota PI-1 wine & 1.21 & 1.81 & 14.32 \\
\hline Sapota MY-1wine & 0.90 & 1.12 & 12.15 \\
\hline
\end{tabular}

Table.4 Biochemical composition of sapota must and wine

\begin{tabular}{|l|l|l|l|l|}
\hline Parameters & $\begin{array}{l}\text { Pineapple } \\
\text { PI-1 }\end{array}$ & $\begin{array}{l}\text { Pineapple } \\
\text { MY-1 }\end{array}$ & $\begin{array}{l}\text { Sapota } \\
\text { PI-1 }\end{array}$ & $\begin{array}{l}\text { Sapota } \\
\text { MY-1 }\end{array}$ \\
\hline TSS & 9.0 & 13.0 & 7.34 & 8.21 \\
\hline Total sugar $(\mathbf{g} / \mathbf{1 0 0} \mathbf{~ m l )}$ & 8.9 & 12.96 & 7.3 & 8.28 \\
\hline $\begin{array}{l}\text { Titratable acidity }(\mathbf{g} \text { tartaric acid/100 } \\
\text { ml) }\end{array}$ & 1.35 & 1.0 & 1.21 & 0.90 \\
\hline pH & 3.05 & 3.24 & 3.16 & 3.35 \\
\hline Alcohol $(\%)$ & 12.12 & 10.21 & 14.32 & 12.15 \\
\hline
\end{tabular}

Ascorbic acid

Pineapple being more acidic in nature reported to have maximum ascorbic acid content in pineapple wine with PI-1 then MY1 followed by the same trend by sapota wine. Isolated yeast strain PI-1 reported to contribute more ascorbic acid content in wine then the Brewers yeast. The Ascorbic Acid content in wine prepared from yeast Saccharomyces cerevisiae was supported with Panda et al., 2014 who reported increased trend of ascorbic acid during fermentation with decrease in TSS. Results are in accordance with the findings of Gaharwar et al. 2017 who reported the increased ascorbic acid content in pomegranate wine. 


\section{Alcohol percentage}

Maximum alcohol percentage was obtained in sapota wine with PI-1 (14.32\%) followed by the sapota wine with MY-1 (12.15\%) . Pineapple wine stood next to pineapple wine for alcohol content and observed maximum alcohol \% (12.12\%) with PI-1 followed by MY-1(10.21\%)at 30 days of fermentation of wine samples.

As compared to market yeast the isolated pineapple yeast (Saccharomyces cerevisiae) PI-1produced more alcohol in wine samples. The alcohol percentage in sapota are in confirmation with the findings of Gautam and Chundawat 1998. The increase in alcohol content was due to the conversion of sugars to alcohol during ageing of wine. The results are supported by Sapna et al. 2002, Okoro, C. 2007 and Gaharwar et al., 2017.

\section{Organoleptic evaluation}

The Pineapple wine prepared with PI-1 yeast was slightly acidic which imparted a unique flavour and aroma to the pineapple wine. Organoleptic evaluation showed that the pineapple wine with PI-1 had a strong exotic taste and the flavour which scored the higher points among all the wine samples. The other wine pineapple with MY-1 and Sapota with PI-1 scored the points above 15.00 and categorized under Good Quality wine. The results are supported by Ibegbulem, et al., 2014 and Panda, et al.,2014. However, sapota wine prepared with MY-1 scored the points 12.97 that categorized under medium quality wine. Therefore, it showed that, yeast determined the wine quality even the source is same.

In the present study, biochemical and sensory attributes of functional wine from pineapple and sapota fruits were developed and evaluated for the comparative performance of PI-1 isolates with Market yeast for quality wine production. From the experiment it was concluded that, the isolated strain from rotten pineapple PI-1 was found most suitable for wine production of both pineapple and sapota fruits. Also from the organoleptic evaluation, pineapple and sapota wines with PI-1 yeast were found most acceptable for winery.

\section{References}

Aakriti Guleria.2014. Production of grape wine by the use of yeast Saccharomyces cerevisiae 3(6).22778160

Adaikan, P. and A. A. Ganesan, 2004. Mechanism of the oxytoxic activity of Comosus proteinases. $J$ Pharm.Biol., $42(8): 646-655$.

Amerine, M.A.; H.W. Berg and W.V. Cruness. 1972. The technology of wine making $3^{\text {rd }}$ edition. $A V I$ Publishing Company, West Port. Connecticut.

Berry, C., J. J. 1996. First Step in Wine Making. Nexus Special Interests Ltd., Hertfordshire, UK.

Gaharwar, Anjali M.; Ughade Jayashri D.; MeghaMadke; ChetanLokhande and Ram Nagarkar 2018. Study on preparation of roselle and fruits blended roselle wine using yeast Saccharomyces cerevisiae. J. of Pharmacognosy and Phytochemistry .7(6): s 1338-1341.

Gaharwar, Anjali., Jayashri, Ughade., Bhavna Surduse., Neha Shedmake., Priyanka., Allarwar and Pooja, Sidam, 2017. Studies on screening of different pomogranate cultivars for wine production. Int. J. Curr. Microbial App. Sci. Sp. Issue. 5:365-372.

Gautam,S.K and Chundawat, B.S.1998. Standardization of technology of Sapota wine making. Indian food Packer.52(1):17-21.

Ibegbulem, C.O. 2014. Effects of processing pineapple-based must into wine by 
anerobic fermentation. American J. of Food Technology 9 (3):162-171.

Idise, and Okiemute Emmanuel, 2012. Studies of wine Produced from Pineapple (Ananascomosus) Internatonal J. for Biotech. and Molecular Bio. Res. Vol.3(1), pp.1-7.

Idolo, Ifie., Taiwo O. Olurin and O. Aina Johnaon, 2012. Production and quality attributes of vegetables wine from Hibiscus Sabdariffa Linn. African J. of Food Sci. Vol.6(7), pp.212-215.

Jacobs, F. 2001. Making Wine from Pineapple. Ihem Davis Press Ltd. Owerri.

Narendranath, N. V.and R. Power 2005. Relationship between $\mathrm{pH}$ and medium dissolved solids in term of growth and metabolism of lactobacilli and Saccharomyces cerevisiae during ethanol production appl. Environ. Microbial. 71:2239-2243.

Nasir, Armanul., R. Shamin Shafkat., Md. M. Husain., and N. Choudhary, 2017. Isolation of Saccharomuces cerevisiae from pineapple and orange study of metal's effectiveness on ethanol production. Europian J. of Microbiology and Immunology. 7(1), 2-11.

Okoro, C. E. 2007. Production of red wine from Roselle and Paw paw using a palm-wine yeast.Niger Food J.25(2):158-164.

Ortiz, Zamora O; R. Cortes-Garcia; M. Ramirez-Lepe; J. Gomez - Rodriquez and M.G. Aquilar- Uscanga 2009. Isolation of ethanol - resistant and osmotolerant yeast from reginal agriculture sources in Mexico. J. of food process engineering 32(5),775786.

Palmeri, M.C.1996. Efficient flotation of yeast cell grown in batch culture.Biotechnol Bioeng. 50(3):24856.

Panda, S. K., U. C. Sahu., S. K. Behera and R. C. Ray, 2014. Fermentation of bael (Aegle marmelos L.) fruits into wine with antioxidants. Food Biosci. 5:3441

Ranganna, S. 1977. Handbook of Analysis and Quality Control for Fruit and vegetables Products, $2^{\text {nd }} E d n$.TataMc. Graw-Hill Pub. Co. Ltd, New Delhi.

Saha, Jayata, 2016. A table wine from tropical fruits using natural yeasts isolates. $J$. of Sci.Technol. 53(3) :1663-9.

Sapana, V., M. Vaundhara and M. L. Annapurna, 2002. Fermented beverage from Spices- a nutrceutical drink. $J$. Spices aromatic crops. 11:106-111.

Thoukis, G., M. Ueda and D. Wright, 1965. The formation of succinic acid during alcohol fermentation. Am,J. Nutr., 7:513-520.

Tochi, B. N., Z. Wang., S. Y. Xu and W. Zhang, 2008. Therapeutic application of pineapple protease (Bromelain) : $A$ review. Pak J.Nutr.,7:513-520.

Vaughan- Martini, A; A. Martini 1998. Determination of ethanol production. The yeasts A taxonomic study. Eds.p.107.

\section{How to cite this article:}

Anjali Gaharwar, Shinde R.M., Wasule. D.L., Bharsakhale. R.D., Yelme M.P., Khode Vaibhavi and Manisha Sonule. 2020. Studies on Isolation of Yeast and Its Comparative Performance for Quality Wine Production from Pineapple and Sapota Int.J.Curr.Microbiol.App.Sci. 9(01): 1306-1313. doi: https://doi.org/10.20546/ijcmas.2020.901.144 